\title{
Financial Inclusion Remodeling: Including the Excluded Masses
}

\author{
Raja R.R. Singareddy, ${ }^{+*}$ Pratyush Ranjan, ${ }^{\dagger}$ A. Balamurugan ${ }^{\dagger}$ and C. Shabana ${ }^{+*}$
}

\section{Abstract}

Economic development is possible only if a significant share of the population develops a culture of savings. This culture is conceivable through financial inclusion, which widens the resource base of the financial system, thus, bringing in the marginalised and low-income sections within the purview of the formal banking sector. The inclusion of the marginalised section of society helps in shielding the financial wealth and various other resources in exigent situations. The study captures the discernible trends and practices present in an emerging country like India.

Moreover, financial inclusions reduce the scope of exploitation of the weaker sections of the society by providing secure and easy access to formal credit. Hence, in this study, we have considered the case of India for understanding the role of financial inclusion in economic development. The Indian government aims at providing easy access to finance for those who have remained from the reaches of banking and financial systems through the policy of Pradhan Mantri Jan Dhan Yojna. Under this policy, the government-owned public-sector banks have given many incentives to the marginalised sections so that they do not feel burdened by the rules and regulations of the regular banking system. The primary objective of this article is to critically review the policy as a programme with a focus of financial inclusion of the under-served population.

Keywords: Financial policy, Formal Banking, Low-income groups, Economic development, India

\footnotetext{
${ }^{+}$Research Scholar, XLRI Jamshedpur, India - 831001

${ }^{*}$ Corresponding Author, Emails: fb14004@astra.xlri.ac.in and fb14005@astra.xlri.ac.in (C) 2019 Singareddy et al. This is an Open Access article distributed under the terms of the Creative Commons Attribution License (http://creativecommons.org/licenses/by/2.0), which permits unrestricted use, distribution, and reproduction in any medium, provided the original work is properly cited.
} 


\section{Introduction}

The Situation Assessment Survey NSSO (National Sample Survey Office) 2003 (MoSPI, 2012) pointed out that even in 2003, 51.4 per cent of the households in India were not in a position to avail credit either from the institutional or noninstitutional sources. Of the total 51,770 farm households surveyed in 6638 villages, only 27 per cent availed credit from the formal sources (MoSPI, 2012; Rangarajan et al., 2007). A very small portion of the under-served population only avails credit owing to the low percentage of credit availability for this section of the society. Hence, the Indian government has implemented various measures to address the issue. One such crucial measure to address this lacuna at the macro level with much fanfare was the 'Pradhan Mantri Jan-Dhan Yojana' [can be translated as Prime Minister Public Money Scheme].

On the auspicious moment of Independence Day, that is, on 15 August 2014, the Prime Minister of India made a grand declaration of the new scheme: 'Pradhan Mantri Jan-Dhan Yojana'. This scheme was a National venture on Financial Inclusion $^{1}$ and had an integrated approach towards obtaining total financial inclusion in the country. The primary intention of the scheme was to open one crore bank accounts on an opening day, and therefore, about 60,000 camps were conducted to enable such a gigantic task. However, the initial response was more than expected, as about 1.5 crores (15 million) bank accounts were opened across the country.

The opening of a large number of accounts bears testimony of the enthusiasm displayed by these public sector banks. The State Bank of India alone started 11,300 camps exclusively for opening the Jan Dhan accounts. By September 2014, 30.2 million accounts were opened, and an amount of around ₹15000 million (US\$240 million) was deposited under the scheme. Approximately 74 per cent of the accounts opened is no frill account. Moreover, the scheme has an attractive option of opening a new bank account with zero balance, and it

\footnotetext{
${ }^{1}$ Financial Inclusion as defined by Reserve Bank of India (RBI) "is the process of ensuring access to appropriate financial products and services needed by vulnerable
}

even facilitates the account holder by providing accidental insurance of ₹ 0.1 million and regular life insurance of $₹ 30,000$. Furthermore, the Government has announced an overdrawn facility of ₹5000 after an account successfully operates for six months (Pradhan Mantri JanDhan Yojana, Department of Finance services, Ministry of Finance). It was testified that 312 million bank accounts had been opened with deposits more than ₹755.72 billion (approximately 10 billion USD) as of February 2018 (Ministry of Finance, 2018).

Though the intended objective of this policy is to ensure financial mobility and credit availability for the under-served population, in the long run, the scheme has to address certain implementation issues. This review takes note of the initiatives taken under this policy, its impact and highlights the shortcomings in its execution, which needs to be improved for its successful implementation in the emerging economies. In this review, primarily a brief overview of the present scenario of financial inclusion in India is provided along with a discussion about 'microfinance' as a mechanism to enhance the accessibility of the scheme for the under-served population. Subsequently, the review highlights the achievements of the policy and the hurdles faced during implementation. Finally, the strategic initiatives for attaining the desired objectives are shared.

\section{Overview of the Present Scenario}

The World Bank report of 2015 classifies India as a lower-middle-income economy (World Bank, 2015). India is the second most populated nation-state in the world with 70 per cent of its population living in rural areas and 60 per cent of the population is dependent on agriculture. Rural India is mainly dependent on the agricultural sector, which is monsoon-driven. Therefore, the economic status of the majority of the rural population is linked with the natural environmental factors that are erratic and unpredictable. Furthermore, there are many rural people in the category of lower-middle and

groups such as weaker sections and low income groups at an affordable cost in a fair and transparent manner by mainstream institutional players" (RBI, 2014). 
low-income groups, whose standard of living is relatively low. ${ }^{2}$ The primary factor for the high incidence of rural poverty is the low asset base. According to the Credit Suisse (2017), the bottom 70 per cent of the population holds only $7 \%$ of the total wealth of India, which has caused low production capacity both in the agricultural (which contributes around $22-25 \%$ of the GDP) and manufacturing sector (World Bank, 2015).
There has been a big push by both RBI and the Central Government to help the poor and rural population so that they have access to the institutional sources. However, one notices that there is an extended road ahead before the financial services become accessible, affordable, and convenient. In Table 1, it is shown that the credit-deposit (C-D) ratio of rural India depicts a wide gap that needs to be filled because nearly half the rural districts (44.38\%) has 50 per cent or less credit ratio.

Table 1: Distribution of Rural Districts Classified by Credit-Deposit Ratio

\begin{tabular}{|c|c|c|c|}
\hline C-D Ratio (\%) & Districts & Deposits & Credit \\
\hline $0-25$ & 82 & 19.6 & 5.8 \\
\hline $25-50$ & 206 & 37.8 & 19.6 \\
\hline $50-60$ & 46 & 5.5 & 4.5 \\
\hline $60-70$ & 47 & 4.7 & 4.4 \\
\hline $70-80$ & 33 & 4.1 & 4.5 \\
\hline $80-100$ & 57 & 8.1 & 10.6 \\
\hline 100 and Above & 178 & 20.2 & 50.5 \\
\hline Total & 649 & 100.0 & 100.0 \\
\hline
\end{tabular}

\section{Government Ownership of Banks}

The government plays a very crucial role in the national financial system for the social and economic development of the country. From the financial perspective, the government's participation is related to diminishing the inability of the private banks for channelising their savings to promote the needy and strategic sectors of the country. Furthermore, from a social perspective, the government's role is vital for the augmentation of the employment opportunities, subsidies, and other societal benefits. The nationalisation of banks in the developing countries has always been accompanied with terrible losses. However, it brought success to trade development by facilitating the participation of government in financing trade-related entities, savings, productivity growth, and factor accumulation. According to the developmental and political

\footnotetext{
${ }^{2}$ As of 1 July 2016, low-income economies are defined as those with a GNI per capita, and it is calculated using the World Bank Atlas method, of $\$ 1,025$ or less in 2015; lower
}

theories, the government's possession of the banks is most suitable for the underdeveloped countries and countries with weak financial system (Burgess and Pande, 2005).

In India, the nationalisation of banks was brought about with the same socio-economic considerations as described above. Considering the level of unemployment, regional disparities, and channelling of funds only to large borrowers, the Government of India initiated nationalisation for broader social purpose of extending the banking sector to the unbanked regions as well as for making credit available to all the economic segments. Keeping these objectives in mind, the nationalisation of banks in India started in 1969 with the 14 largest commercial banks that had total deposits of approximately ₹500 million in each of them, which contributed about 56 per cent of the aggregate deposits of all commercial banks.

middle-income economies are those with a GNI per capita between $\$ 1,026$ and $\$ 4,035$. 
These 14 commercial banks along with the State Bank of India (previously, Imperial Bank, which was nationalised along with the incorporation of RBI) constituted about 85 per cent of the aggregate deposit in the banking sector (Banerjee et al., 2004). After the nationalisation of the major banks in the country in 1969, the commercial banks were directed to open branches of their banks in the rural areas of India. The setting up of rural branches of these banks resulted in increasing the number of banks in the rural areas from 1,833 in 1969 to approximately 47,000 in 2016. Furthermore, significant efforts were made to improve the flow of formal credit to the agricultural sector. The share of formal institutional credit in the country increased from 9 per cent in 1951 to about 61 per cent in 2013 (Kumar et al., 2015). Institutional credit lending has been a vital feature of the rural credit and has engrossed continuous attention of the emerging economies, even though there is informal credit lending facility alongside the formal sector (Guirkinger, 2008).

\begin{tabular}{|l|r|l|r|}
\hline \multicolumn{2}{|c|}{ Table 2: The Share of Formal and Informal Sources } \\
\hline Type & $\%$ & Type & The share of informal sources \\
\hline Government & 3.61 & Employer or landlord & 2.34 \\
\hline Cooperative society & 25.37 & $\begin{array}{l}\text { Agricultural professional or } \\
\text { moneylender }\end{array}$ & 64.05 \\
\hline Bank & 71.02 & Shopkeeper \\
\cline { 3 - 4 } & & Relatives or friends & 4.93 \\
\cline { 3 - 4 } & 100.00 & Others & 24.03 \\
\hline Total & 63.56 & $\begin{array}{l}\text { Total } \\
\text { Informal sources as a share of total } \\
\text { loans }\end{array}$ & 100.00 \\
\hline $\begin{array}{l}\text { Formal sources as a share of total } \\
\text { loans }\end{array}$ & & & 36.44 \\
\hline Source: Kumar et al., 2017 & &
\end{tabular}

Table 2 shows the different sources of informal lending wherein the money lenders account for a major chunk of $64 \%$ of the credit. Similarly, among the formal sources, banks have been the major lender, as they provided 71 per cent of the total credit. Table 3 shows the pattern of borrowing by agricultural households. Agricultural households are categorised into four groups: non-borrowers, borrowers from informal sources, borrowers from formal sources, and borrowers from both the formal as well as informal sources. In Table 3, it is shown that nearly 48 per cent of agricultural households does not borrow from any sources, thus keeping away from participating in the financial sector. However, 23 per cent of them have reported about borrowing from formal sectors, 16 per cent from informal sectors, and 13 per cent from both the sources.

Besides the presence of $R B I$, the government established NABARD (National Bank for
Agricultural and Rural Development) to bridge the difference in financing activities of rural population relative to the urban population. The post-independence period witnessed that the people of the rural areas are exploited at the hands of the lenders and traders owing to their need for credit. Credit was granted at exorbitant interest rates, which eventually pulled the nonpayers into a debt trap. For prohibiting this misuse, NABARD was established with the objective of providing easy credit to the rural population. Though RBI is the country's banking apex body, NABARD has been provided with the power to regulate all the credit and banking undertakings of rural India.

Though NABARD has been ascertaining a step in this direction, the concern with the official banking system is that it requires some form of collateral to issue credit. One of the major reasons attributed to the lack of credit accessibility for the larger population is the 
inability to meet the collateral requirements and the associated procedure and formalities (Baruah, 2014). The rural populace in need of exigent credit usually has no collateral to offer. Consequently, they do not stand a chance to have access to the formal banking system. To address this gap and help people with no recourse for collateral, the self-help groups (SHG) have appeared on the scene. They are positively linking the gap between formal credit structure and rural population (Singh, 2016).

\begin{tabular}{|c|c|c|c|c|c|c|}
\hline \multicolumn{5}{|c|}{ Distribution of households by borrowing (\%) } & \multicolumn{2}{|c|}{$\begin{array}{c}\text { The share of formal and } \\
\text { informal credit in } \\
\text { borrowing of households } \\
\text { (\%) }\end{array}$} \\
\hline $\begin{array}{l}\text { Land } \\
\text { class }\end{array}$ & $\begin{array}{c}\text { Non- } \\
\text { borrower }\end{array}$ & $\begin{array}{l}\text { Formal } \\
\text { sources } \\
\text { only }\end{array}$ & $\begin{array}{l}\text { Informal } \\
\text { sources } \\
\text { only }\end{array}$ & $\begin{array}{c}\text { Both } \\
\text { simultaneously }\end{array}$ & $\begin{array}{c}\text { Formal } \\
\text { credit }\end{array}$ & $\begin{array}{l}\text { Informal } \\
\text { credit }\end{array}$ \\
\hline Marginal & 54.67 & 14.77 & 21.68 & 8.88 & 54.95 & 45.05 \\
\hline Small & 48.32 & 24.23 & 14.17 & 13.27 & 64.26 & 35.74 \\
\hline Medium & 41.47 & 29.98 & 11.57 & 16.98 & 67.13 & 32.87 \\
\hline Large & 28.45 & 39.06 & 8.92 & 23.58 & 74.89 & 25.11 \\
\hline All & 47.94 & 22.78 & 16.21 & 13.07 & 63.56 & 36.44 \\
\hline
\end{tabular}

Source: Kumar et al., 2017

\section{Microfinance: Issues of Concern}

Banks have been able to co-opt with the selfhelp groups leading to financial inclusion. microfinance organisations have further played a crucial role in this process. In the recent past, microfinance has been effective in the empowerment of women and poverty alleviation. The different groups that form the Microfinance Institutions (MFI) are Refinance Institutions, Banks, NGO's, and Self-help groups. The MFIs help in raising the standard of living by giving small loans and enabling them to raise savings. Table 4 gives information about the loan disbursed to the MFIs through various financing agencies.

One of the ways through which the entry to the formal banking services has been successfully delivered since the early 1990s is by linking the Self Help Groups (SHGs) with banks. The ties of SHGs with banks aim at using the intermediation of SHGs between banks and the rural poor for bringing down the operating costs for both banks as well as the rural clients. The key objective of this linkage is to develop some complementary credit strategies for fulfilling the credit requirements of the rural clients by coalescing the flexibility and approachability of the informal credit system with the power of technical and organisational competencies and financial means of the formal financial organisations. SHGs are groups of women who get together and pool their savings for providing loans to the members. This is usually facilitated by an NGO that not only helps in forming the groups but also nurtures them. SHGs are given loan against the guarantee of the group members. Banks are willing to provide credit to such groups at reasonable interest rates because the recovery rate has been very high. Most of the loans are of small size and used for small business or smoothening consumption. Credit is further provided for agricultural activities and other livelihoods.

The financial inclusion attained through SHGs is sustainable and scalable owing its various positive features. Microenterprise loans can be profitable for borrowers as well as for the lenders, thereby, making microfinance one of the most effective poverty-reducing strategies 
(Vyas and Raman, 2012). One of the characteristic features of the SHG has been the high recovery rate. However, the extent of SHGs is very uneven across India and is more concentrated in the southern states.

For private banks, the lower cost of funding and gain in size and scale provide the choice for subsidisation, and their interest rates are more viable compared to the MFIs, but they have not been effective in dealing with the last mile issue. The partnering with SHGs and MFIs considering the realistic cost of funding from the banks has been seen as a more optimal approach (Thorat, 2007).

\begin{tabular}{|c|c|c|c|c|c|}
\hline $\begin{array}{l}\text { Financial } \\
\text { Agency }\end{array}$ & Year & $\begin{array}{l}\text { Loans disbursed } \\
\text { during the year to } \\
\text { MFls }\end{array}$ & $\begin{array}{l}\text { Amount } \\
\text { (Fmillion) }\end{array}$ & $\begin{array}{c}\text { Loan } \\
\text { outstanding } \\
\text { against MFIs }\end{array}$ & $\begin{array}{l}\text { Amount } \\
\text { (Fmillion) }\end{array}$ \\
\hline \multirow{4}{*}{$\begin{array}{c}\text { Commercial } \\
\text { Bank }\end{array}$} & 2009-10 & 645 & $80,363.1$ & 1,407 & $100,953.2$ \\
\hline & 2010-11 & 460 & $76,010.2$ & 2,153 & $106,468.4$ \\
\hline & $2011-12$ & 336 & $49,509.8$ & 1,684 & $98,109.8$ \\
\hline & $2012-13$ & 368 & $74,226.6$ & 1,769 & $124,677.2$ \\
\hline \multirow[t]{4}{*}{ RRBs } & $2009-10$ & 46 & 241.4 & 103 & 522.2 \\
\hline & 2010-11 & 9 & 41.6 & 23 & 420.1 \\
\hline & 2011-12 & 113 & 132.8 & 128 & 375.1 \\
\hline & $2012-13$ & 14 & 45.8 & 153 & 706.6 \\
\hline \multirow{4}{*}{$\begin{array}{c}\text { Cooperative } \\
\text { Banks }\end{array}$} & 2009-10 & 0 & 0 & 3 & 0.1 \\
\hline & 2010-11 & - & - & - & - \\
\hline & $2011-12$ & 4 & 16.1 & 19 & 47.5 \\
\hline & 2012-13 & 3 & 4.0 & 18 & 68.3 \\
\hline \multirow[t]{4}{*}{ SIDBI } & $2009-10$ & 88 & $26,657.5$ & 146 & $38,082.0$ \\
\hline & 2010-11 & 2 & $8,437.8$ & 139 & $30,417.7$ \\
\hline & 2011-12 & 12 & $2,394.2$ & 129 & $15,971.1$ \\
\hline & $2012-13$ & 41 & $4,082.7$ & 102 & $18,806.3$ \\
\hline \multirow[t]{4}{*}{ All Agencies } & 2009-10 & 779 & $107,285.0$ & 1,659 & $139,557.5$ \\
\hline & 2010-11 & 471 & $84,489.6$ & 2,315 & $137,306.2$ \\
\hline & 2011-12 & 465 & $52,052.9$ & 1,960 & $114,503.5$ \\
\hline & $2012-13$ & 426 & $78,395.1$ & 2,042 & $144,258.4$ \\
\hline
\end{tabular}

Sources: NABARD (2013); Micro Credit Innovation Department (MCID), Mumbai

\section{Brief Description about Self Help Groups}

Self-help groups are generally homogenous groups of 10-20 members, which act as a financial intermediary with the following characteristics:

- A homogenous group of 10-20 members

- Periodical meetings

- Periodical savings

- Lending decisions are decided by the group

This model is well accepted by the mainstream banks and has been linked to the nationwide bank linkage programme. The members of the
SHGs cannot individually avail loans or any other financial services. However, MFIs breaks this vicious cycle of entrapment through the formation of these groups.

It is interesting to note that multinational companies have taken advantage of the existing structures of microfinance for venturing into the rural markets in a big way. Many multinational companies like Hindustan Unilever Limited, Coca-Cola, Nokia, Bajaj Allianz, Godrej, Airtel are offering their goods and services that are suitable for the rural segment (Ramadugu and Pasupuleti, 2009). 


\section{Who are the customers of microfinance?}

The typical customers include low-income persons, small farmers, and people engaged in petty trade, daily wage labour, etc. In the urban areas, the customers of microfinance are from varying backgrounds such as street vendors, artisans, service providers, small shop owners, etc. However, these customers have one thing in common, that is, their unstable source of income and inadequate access to formal financial sectors. The accessibility to credit is directly related to income, that is, the poorer a person is, the lesser is their accessibility to financial services. Therefore, customers who are illserved by formal financial institutions are the customers of microfinance.

\section{Activities in Microfinance}

Microfinance is a generic term, and it includes micro-loans, micro-savings, micro-insurance, remittances, and other financial services for lowincome customers. Micro-financing covers the following activities under its ambit:

Microcredit: Bank or any other financial institution gives small loan to a client, which can be offered to an individual, even without any collateral, or it could be offered through group lending.

Micro-savings: This service allows an individual to save small amounts for future usage. There are no pre-set minimum balance requirements. Therefore, this provision of depositing small savings helps the households to meet the unexpected expenses (Gupta, 2014).

Microinsurance: The access to insurance services enables entrepreneurs to focus on improving their businesses while reducing other risks related to property or health.

Remittances: This service helps people to transfer funds from one place to another, even across boundaries, which is relatively a steady source of funds in comparison to the above sources (Gupta, 2014).

\section{Microfinance: Gender Empowerment}

Microfinance has improved and enhanced the dignity of women, which in turn is a vital contribution to women's empowerment. One notices the presence of a specific gender dimension in microfinance, as most SHGs comprise of women and are exclusively the domain of women (Edward and Olsen, 2006). Fundamentally, the two factors seem to weigh in their favour. First, there is a general perception and belief that women are much more responsible than men. Moreover, women folk run the household; hence, they are aware of the needs of the family and are less likely to squander the credit on unproductive consumption. Furthermore, they are less likely to default because their sense of honour weighs more heavily on them than men (Thorat, 2007b).

Second, women are bestowed with the perception that they are doubly oppressed for being poor and subordinate in status. Contribution to women's ability for income will result in their economic empowerment, which in turn will enhance the wellbeing of women and their families and broader social and political empowerment. The microfinance programs aiming for women have become a significant plank of poverty alleviation and gender strategies. With the increased indication of the importance of gender equality to poverty reduction and women's higher credit repayment rates, a broad consensus is reached on the interest of targeting women.

Microfinance has been in existence for over three decades, and yet it plays a modest role in the country. In spite of the concerted efforts, only 5 per cent of poor rural populations have access to microfinance, whereas microfinance has achieved 65 per cent penetration in Bangladesh (Ahmed et al., 2016). There has been a skewed growth of SHGs across various regions in India. The cumulative share of non-southern regions increased from 29 per cent as on March 2001 to 48 per cent as on March 2007. This is mainly for the presence of a large number of NGOs operating in the South Region. While estimating the impacts of microfinance on savings and borrowings, Khandker (1998) found that microcredit not only increases automatic savings but also induces voluntary savings. Apart from the financial services, MFIs are also involved in providing training and imparting 
knowledge. Hence, microfinance is treated as a developmental tool in the present scenario (wood Joanna, 2000).

\section{Jan Dhan Yojana: Hurdles to be Crossed to Accomplish its Goal}

The government wanted to reach rural India and therefore began the Swabhiman Rural Banking scheme. Though its objectives were reasonable, it was a failure even before its implementation owing to the absence of concrete measures. It was merely an account opening exercise and practically served no other purpose. The Pradhan Mantri Jan Dhan Yojana (PMJDY) seems to be traversing the same path unless corrective measures concerning the demand side issues of economic empowerment are implemented and the absorptive capacity of credit is addressed. The slogan of Jan Dhan Yojana "Mere Khata, Bhagya Vidhata" (meaning in English - 'My Bank Account - The Creator of Good Fortune) has the inherent characteristics of an account focused approach rather than a service-based approach. Contrary to this, the Prime minister's slogan, "Sabka Saath, Sabka Vikas" (meaning in English Together with all, Development for all) is probably a holistic approach towards financial inclusion.

\section{Implementation of the Scheme}

The primary reason to begin PMJDY is that only 145 million households had access to banking services while 105 million were outside the system according to the 2011 census. Thus, about two-fifths of the population had no access to the banking services; hence, there was no probability of their having any access to broader financial services. The access to banking facilities and financial services is not an end in itself, but a path to better living standards and better livelihoods. The feature of connecting the overdraft facility to a credit bureau for enabling low-income households to build credit histories is an excellent initiative. This feature enables the beneficiaries of the scheme to become involved in mainstream banking and financial services, which could mitigate the information gaps thus leading to excess borrowing and higher credit risks by the lenders (Nguyen and Nguyen, 2018). The commercial correspondents who link the account holders with the bank get provision for a minimum monthly income of ₹ 5,000, which is likely to aid the implementation process. It is worth noting that many villages with around 2000 people do not have a bank branch. The speed of opening branches in small towns and villages has been reasonable because these branches have been opened with the intention of providing the necessary bank facilities to all villages by 2018 as envisaged in PMJDY.

The targets set for PMJDY are indeed very ambitious. The scheme dramatically increases the demand for banking and related services massively. India's insurance sector is not vigorous, as life insurance covers less than 10 per cent of the population, which is very low in comparison to the international standards. Furthermore, the geographical coverage of the insurance companies is limited and inadequate. Hence, this situation creates a wide gap between the demand and supply of banking and financial services. The recent report by World Bank Global Findex data (2017) indicates that 80 per cent of Indian adults has a bank account, which depicts the success of the policy measure. While the growth in the percentage of adults having bank accounts is certainly impressive (80\% in 2017 from $53 \%$ in 2014), about 48 per cent of them have made no withdrawal or deposit in the previous year (Felsenthal and Hahn, 2018).

Financial inclusion is not merely about having bank accounts; rather it is notably about using these accounts for accessing the formal credit sources. Though the policy has accomplished to get numerous people to open bank accounts, its major drawback is that there is no proportionate growth in the usage of these accounts, accessibility of formal credit, or savings in financial institutions, particularly among the marginalised and poorer sections.

\section{Strategy for Attaining Objectives}

For the successful implementation of the policy, the following strategies need to be executed. One, the Postal Department should be given a full banking license, as it has the best coverage facility in the country. Two, the focus on branchless banking and micro-branches has to be enhanced at higher speed. For network 
expansion and geographical coverage of the banks, the primary pillar of PMJDY must be the expansion of banking network of the country to reach out to the financially excluded segment. The 0.6 million villages across the entire country are to be mapped according to the service area of each bank for determining one fixed point, which is known as the Sub Service Area.

In its current form, the scheme heavily relies on Business Correspondents and the fixed-point Bank mitras, which were the basic blocks of the previous government scheme that failed. Though the proposed transaction fees of 2 per cent is a decent start to make it sustainable; it still falls short of the recommended 3 per cent as proposed by various committees. Moreover, there is a possibility that the blame game will start all over again. The banks eventually need to evolve a lower cost model for providing longterm service and enabling the opening of bank accounts.

In addition to the above woes, it is noticed a declining growth rate of the Self-Help Groups as well as the Joint Liability groups. The creditlinked to livelihood is in a pathetic state. Though women and the marginalised section are given priority in such schemes, the reality is different because credit accessibility of such groups is at an alarmingly low level. While National Bank for Rural and Agriculture Development was set up to redress the situation, it too has not been able to achieve its objectives, especially in the area of non-agriculture credit.

For realising financial inclusion, financial literacy has a vital role to play. The role of Panchayati Raj institutions and local bodies cannot be undermined. While the intentions are right, there are many gaps that need to be plugged in. PMJDY is a huge leap towards financial inclusion of the excluded section of the society, which also depicts that the real fight against poverty has just begun.

It has been identified that technology has the potential to address the issues of outreach and credit delivery in rural areas in a feasible manner. Therefore, banks have been counselled to make active use of information and communications technology (ICT) and to offer secure banking services that will enable operation of the accounts even by illiterate customers through the use of biometrics, thus, guaranteeing the security of transactions and enhancing confidence in the banking system. Technology is bridging the gap between the customer and the banks; hence, the banks are aiming to make active use of information and communications technology (ICT). The technology developed for enabling illiterate customers to operate accounts using biometric can offer secure banking services, thus, guaranteeing the security of transactions and enhancing confidence in the banking system (Bansal, 2014). With a near comparable ratio of people holding mobile phones $(59.13 \%$ of the population; Statista, 2018) and people holding bank accounts ( $80 \%$ of the population; Economic Times, 2018), it is evident that mobile technology is crucial for reaching a greater mass of the excluded.

\section{Concluding Remarks}

Financial inclusion broadens the resource base of a financial system and reduces the scope of exploitation of the weaker sections of the society by providing secure and easy access to formal credit. Considering the marginalised and lowincome sections within the purview of the formal banking sector will help in protecting the financial wealth and various other resources in critical situations. Although the core philosophy of the PMJDY falls under this purview and has been effectively implemented, a sustainable continuance of the scheme is debatable. With almost half the bank accounts opened under this scheme being bereft of active transactions, the contribution of such bank accounts to the individual as well as to the economic development is uncertain. The successful implementation of the project critically depends on the combination of political will and support of bureaucracy and Reserve Bank of India. Economic development is largely possible through the development of a culture of savings among a higher proportion of the population. Hence, the follow-up plans of inactive accounts and incentives for tenable account activities are in dire need for sustainable continuance of the 
scheme. With its initial success among the masses and the effective coordination and dedication of the formal banking sector, this scheme has wider opportunities to open the door for greater economic participation.

\section{References}

Ahmed, M.K., Asadullah, M.N. and Kambhampati, U. (2016). The effect of formal banks on household income and poverty in Bangladesh, Malaysian Journal of Economic Studies, 53(2), pp. 173-193.

Bansal, S. (2014). Perspective of technology in achieving financial inclusion in rural India, Procedia Economics and Finance, 11, pp. 472-480.

Baruah, P.B. (2014). Financial Access of Unorganised Manufacturing Enterprises in Assam, Space and Culture, India, 2(2), pp. 4-16, https://doi.org/10.20896/saci.v2i2.84

Burgess, R. and Pande, R. (2005). Do rural banks matter? Evidence from the Indian social banking experiment, American Economic Review, 95(3), pp. 780-795.

Banerjee, A.V., Cole, S. and Duflo, E. (2004). Banking reform in India, India Policy Forum, Brookings Institute and NCAER, available at: https://economics.mit.edu/files/508 (accessed 21 December 2018).

Credit Suisse (2017). Global Wealth Report 2017, available at: https://static.poder360.com.br/2017/11 /global-wealth-report-2017-en.pdf (accessed 21 December 2018).

Economic Times (2018). Number of adult Indians with bank accounts rises to $80 \%$, available at: https://economictimes.indiatimes.com/i ndustry/banking/finance/banking/numb er-of-adult-indians-with-bank-accountsrises-to-80/articleshow/63838930.cms (accessed 21 December 2018).

Edward, P. and Olsen, W. (2006). Paradigms and Reality in Micro-Finance: The Indian
Case, Perspectives on Global Development \& Technology, 5(1/2), pp. 31-54.

Felsenthal, M. and Hahn, R. (2018). Financial Inclusion on the Rise, But Gaps Remain, Global Findex Database Shows, available at

https://www.worldbank.org/en/news/p ress-release/2018/04/19/financialinclusion-on-the-rise-but-gaps-remainglobal-findex-database-shows (accessed 21 December 2018).

Guirkinger, C. (2008). Understanding the coexistence of formal and informal credit markets in Piura, Peru, World Development, 36(8), pp. 1436-1452.

Gupta, S. (2014). Micro-Finance: A Brief Description. International Journal of Multidisciplinary Approach \& Studies, 1(4), pp. 319-327.

Khandker, S.R. (1998). Fighting poverty with microcredit: experience in Bangladesh, Oxford, MA: Oxford University Press.

Kumar, A., Mishra, A.K., Saroj, S. and Joshi, P.K. (2017). Institutional versus noninstitutional credit to agricultural households in India: Evidence on impact from a national farmers' survey, Economic Systems, 41(3), pp. 420-432.

Kumar, A., Singh, R., Jee, S., Chand, S., Tripathi, G. and Saroj, S. (2015). Dynamics of Access to Rural Credit in India: Patterns and Determinants, Agricultural Economics Research Review, 28(conf), pp. 151-166.

Ministry of Finance (2018). 31.20 crore accounts opened under Pradhan Mantri Jan-Dhan Yojana (PMJDY) with aggregate deposit balances Rs. 75,572.09 crore as on 28.2.2018, available at: http://pib.nic.in/newsite/PrintRelease.a spx?relid=177851 (accessed 21 December 2018).

Ministry of Statistics and Programme Implementation (MoSPI) (2012). Situation Assessment Survey of Farmers: 
NSS 59th Round Sch 33: 2003, available at:

http://mail.mospi.gov.in/index.php/cata log/124/download/1426 (accessed 21 December 2018).

NABARD (2013). Status of Microfinance in India 2012-13, Micro Credit Innovation Department (MCID), Mumbai.

Nguyen, H.T.K. and Nguyen, D.T. (2018). Globalisation and bank performance in Vietnam, Malaysian Journal of Economic Studies, 55(1), pp. 49-70.

Ramadugu, N.S. and Pasupuleti, G. (2009). Rural Marketing in India: Retailing through Microfinance Institutions, available at: http://ibscdc.org/Case_Studies/Marketi ng/Marketing\%20Strategies/MM0068.ht m (accessed 21 December 2018).

Rangarajan, C., Kaul, I. and Seema, S. (2007). Revisiting employment and growth, ICRA Bulletin-Money \& Finance, 3(2), pp. 5768.

Reserve Bank of India (2014). Financial Intermediation for All - Economic Growth with Equity, available at: https://rbi.org.in/scripts/FS_Speeches.a spx? Id $=912 \& f n=2754 \quad$ (accessed 6 February 2018).

Singh, M. (2016). Microfinance-A Boon to the Poor: The Role of Nabard, in Vaibhav, Pandey, N. and Pradhan, G.P. (Eds.), Financial Economics and Sustainability Issues in India, New Delhi: Horizon Books, pp. 124-129.

Statista (2018). Number of mobile phone users in India from 2013 to 2019 (in millions), available at: https://www.statista.com/statistics/274 658/forecast-of-mobile-phone-users-inindia/ (accessed 21 December 2018).

Thorat, U. (2007). Financial inclusion-the Indian experience, Paper presented at the HMTDFID Financial Inclusion Conference.
Vyas, C.S. and Raman, A. (2012). Microfinance Institutions in India: An Overview, International Journal of Marketing and Technology, 2(10), pp. 233-248.

World Bank (2015). Annual Report 2015, available at: http://www.worldbank.org/en/about/a nnual-report-2015 (accessed 21 December 2018).

wood Joanna, L. (2000). Microfinance: Sustainable Banking with the Poor. Washington, DC: World Bank.

\section{Acknowledgement}

We thank the editors of the journal SACl and the anonymous reviewers for the constructive inputs without which this article would not have been possible.

\section{About the Authors}

Raja R.R. Singareddy is a Doctoral Scholar in Management (Finance) at XLRI Jamshedpur. His research interests are in corporate finance, business valuation and analysis, corporate governance, financial inclusion, and business turnaround management.

Pratyush Ranjan is a Doctoral Scholar in Management (Marketing) at XLRI Jamshedpur. His area of interests is sustainability, sustainable marketing, anti-consumption, consumer wellbeing, and business ethics.

A. Balamurugan is a Doctoral Scholar in Management (Marketing) at XLRI Jamshedpur. His area of interests is digital marketing and sustainability. He has industry experience in brand management.

C. Shabana is an Engineering and Management graduate from India. Currently, she is pursuing her Doctoral studies in Information Systems from the XLRI Jamshedpur. Her research interest includes business analytics and data mining. 